\title{
Alkaline DNase
}

National Cancer Institute

\section{Source}

National Cancer Institute. Alkaline DNase. NCI Thesaurus. Code C114793.

An enzyme that is present in human serum and catalyzes the hydrolytic cleavage of phosphodiester bond linkages in the DNA backbone. The relative activity of this enzyme can be used as a marker of therapeutic responses or disease relapse. 